\section{OP-045無阻血と阻血による体腔鏡下腎部分切除 術の周術期成績の比較検討}

\section{岡山大学医学部泌尿器科学}

小林 泰之, 真鍋 大輔, 江原 伸, 雑賀 隆史,

那須 保友, 公文 裕巴

目的：無阻血と阻血による体腔鏡下腎部分切除術の周術期 成績の比較検討を行う。対象と方法：2001 年 1 月から 2005 年 5 月までに岡山大学附属病院にて行った無阻血による体 腔鏡下腎部分切除術 11 例、阻血による体腔鏡下腎部分切除 術 7 例を対象とした。無阻血群では超音波駆動メスにて、 阻血群では腎動脈をクランプ、鋏を用いて腫瘍切除を行っ た。手術時間、出血量、術前後の腎機能について検討した。 無阻血群 5 症例、阻血群 5 症例に対し MAG3 にて患側腎機 能の評価を行った。結果: 阻血群の阻血時間は中央値 35 分であった。手術時間は無阻血群：中央値 180 分、阻血群 : 中央值 200 分であった $(\mathrm{P}=0.9)$ 。出血量は無血群: 中央値 $150 \mathrm{ml}$ 、阻血群 : 中央值 $54 \mathrm{ml}$ であった $(\mathrm{P}=0.04)$ 。腎シン チグラフィーによる患側腎の術後総腎機能比は無阻血群 : 中央值 $44.9 \%$ 、阻血群 $42.1 \%$ であった。無阻血群において 切除断端陽性症例を一例認めた。結諭：阻血による体腔鏡 下腎部分切除術の利点は出血量が少ないことがあげられ た。その結果として、切除ラインが把握しやすく確実な腫 瘍切除が可能と思われる。術後患側腎機能は、両群に有意 な差は認めなかった。

\section{OP-046}

小切開血栓摘出術に経皮的血管内形成術 (以下PTA)を併用した上腕バスキュラー アクセス（VA）血栓塊閉塞例の治療法

\section{関川病院"，鶴見西口病院 ${ }^{2)}$}

暮原 敬八郎 ${ }^{1}$, 三浦 逮子 ${ }^{12}$, 王 恒維 ${ }^{2}$

(目的) 上腕バスキュラーアクセストラブル（以下VAT）の 血栓塊閉塞例に小切開による血栓摘出に、PTAによる狭窄 部拡張術を加えたVAT 治療方法を施行し、良好な結果を得 たので、その有用性について報告する。(方法) 演者は、平成 16 年 4 月から平成 18 年 8 月末迄に総計 671 回の PTA を施 行し、早期成功率 $92 \%$ を維持している。今回、これに含まれ ない、上腕アクセス大血栓塊閉塞 5 例に、約 $5 \mathrm{~cm}$ の U 字切開 にてアクセス静脈上に施行して、アクセスを約 $3 \mathrm{~cm}$ 剥離 · 露出し、次にアクセスに約 $5 \mathrm{~mm}$ の切開を加え、この部から まず中枢静脈内血栓を、次に切開口から $\mathrm{A}-\mathrm{V}$ 吻合部迄の末 梢静脈内の血栓を摘出し、血管切開部を縫合する。その後、 吻合部近位から PTA カテーテルを挿入し、アクセス狭窄部 の拡張術を追加施行して治療を終了した。尚、上記治療は、 血管造影台上にて施行している。(考察結論) 上腕 VATでの 血栓塊閉塞例の治療では、血栓片の動脈内逆流を予防する必 要があり、これら症例への PTA 単独療法は、血栓片による 静脈内陥頓のリスクもあり、成功率に問題がある。このため、 拡張したアクセスに $5 \mathrm{~cm}$ 以上の硬い血栓を伴う上腕 VAT 例には、小切開での血栓摘出後に PTA で追加補正する本法 は、同一血管の再使用等から有効と考える。

\section{OP-047 CAPDカテーテル外部カフ感染を安全 かつ速やかに治療する手術手技}

\section{米沢市立病院泌尿器科}

高岩 正至,片岡 政雄

【はじめに】CAPD カテーテル関連感染の治療の中で、外部カ フ感染を安全かつ速やかに治療することは、カテーテルの生 存と CAPD の存続に関わる。目的】研究目的は外部力フ感染 を安全かつ速やかに治療する手技を確立することである。【 法】カフの長さを $5 \mathrm{~cm}$ と長くしたCAPD カテーテルを 5 年 間に 100 本使用した。また 2005 年 9 月から長さ $2.5 \mathrm{~cm}$ のカフ を $8 \mathrm{~cm}$ 間隔で 2 個装着した CAPD カテーテルを 25 本使用 した。25 本のうち 3 例にて外部カフの外側の感染が治療困難 と判断し 2 個のカフ間の清潔区域でチタニウムアダプターに よるカテーテル一部交換術を施行した。感染カフ部のカテー テルは新カテーテルの走行から $1 \mathrm{~cm}$ 以上離してカテーテル 端には栓をした。同時にカテーテル出口部のカテーテルも栓 をして切断に皮下に埋没させた。結果】125 本のカテーテル の経験から感染は長いカフの外側だけに感染が限局すること が多いことを確認した。皮下に孤立した外部カフの感染は収 束することが多かった。結語】長いカフに生体の結合組織が 入り込むことで、カフの一部に感染が起こっても感染巣が長 いカフ全体に波及するまでには時間がかかる、また感染が修 復される可能性もある。つまり長いカフは感染に強い。そして 外部カフ感染が起こったときは、本法のように感染のない清 潔区域にてカテーテル交換術をすることが重要である。

\section{OP-048 血液透析患者及び腹膜透析患者の末梢血 単球上に発現するTLR（Toll-Like Re- ceptor）に関する検討}

\section{大阪市立大学大学院医学研究科泌尿器病態学 \\ 黑木 慶和, 土田 健司, 長沼 俊秀, 田中 智章, 鞍作 克之, 内田 潤次, 吉村 力勇, 川嶋 秀紀, 杉村一誠, 武本 佳昭, 仲谷 達也}

【目的】近年, TLR（Toll-like receptor）と呼ばれる一群の 受容体が病原体の認識とその後の免疫反応に必須の分子で あることが判明した。血液透析患者、腹膜透析患者におけ るTLRの発現を検討した. 【方法】本研究の趣旨を説明し, 研究参加への同意を得た健常者, 血液透析患者, 腹膜透析 患者より末梢血を採血し末梢血単核球を分離した． $\mathrm{PE}$ 標 識抗 TLR-2 抗体及び抗 TLR-4 抗体で染色し, フローサイ トメトリーを用いてその単球上における発現を測定した. 各患者群間で検討した. [結果】末梢血単球における TLR-2 の発現についてであるが, 健常者群, 血液透析患者群と比 較して腹膜透析患者群では, 有意にその発現は低かった. また有意差一方, TLR-4については健常者群と比較して血 液透析患者群ではその発現程度は有意に低かった. [結論] 血液透析患者では TLR-4の発現が, 腹膜透析患者では TLR-2 の発現が抑制されていた. グラム㓌性菌の菌体成分 であるエンドトキシンや，グラム陽性菌の菌体成分である ペプチドグリカン等への暴露が原因である可能性が示唆さ れた。 